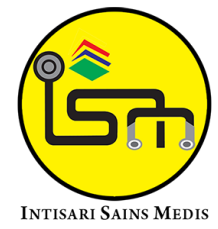

Published by Intisari Sains Medis

\section{Dietary management in colorectal cancer prevention: a review}

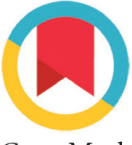

CrossMark

\author{
Yudi Kristanto ${ }^{1 *}$, Angeline Rosa Hartono ${ }^{1}$
}

${ }^{1}$ Faculty of Medicine, Universitas Hang Tuah, Surabaya, Indonesia;

*Corresponding author:

Yudi Kristanto;

Faculty of Medicine, Universitas Hang Tuah,

Surabaya, Indonesia;

yuddy22@yahoo.com

Received: 2021-04-08

Accepted: 2021-10-15

Published: 2021-11-04

\section{ABSTRACT}

Colorectal cancer (CRC) is still a health problem with a high incidence worldwide. Genetic factors and environmental factors are the etiology of colorectal cancer. Eating habits are one of the environmental factors that can be regulated so as to prevent colorectal

cancer. Diet food in the development of colorectal cancer has an important role. Several studies in the last decade have shown an association between the consumption of several foods and nutrients and the risk of colorectal cancer in epidemiological and experimental studies.

Keywords: Colorectal cancer (CRC), dietary, prevention, nutrition.

Cite This Article: Kristanto, Y., Hartono, A.R. 2021. Dietary management in colorectal cancer prevention: a review. Intisari Sains Medis 12(3): 801-804. D0I: 10.15562/ism.v12i3.1020

\section{INTRODUCTION}

Colorectal cancer is a cancer with a high diagnosed prevalence, where there are about 1 million new cases and the death rate reaches 600,000 per year worldwide. ${ }^{1}$ The high incidence of colorectal cancer is found in many western countries, so that colorectal cancer is generally considered a disease of the western lifestyle. Unfortunately, the incidence of colorectal cancer in economic transition countries such as Eastern European countries, most of Asia, and countries in South America is increasing every year. ${ }^{2}$ The change in diet due to globalization is a contributing factor to the increasing incidence, so that a healthy diet and lifestyle have an important role in the primary prevention of colorectal cancer. ${ }^{3}$

There are currently changing dietary trends in high-income communities around the world. The diet pattern followed was the 'western diet' with consumption of processed meat products, high-fat products (milk, butter, eggs, margarine, mayonnaise, and fast food), refined grain products, high-calorie, carbonated and snack. ${ }^{4}$ Whereas in most low-income countries have a wise diet with the dominance of plant foods that are high in fiber and low in fat intake. ${ }^{5}$

The majority of colorectal cancers occur sporadically, where there is no clear family history confirming the presence of inherited mutations that explain the occurrence of cancer. In sporadic cancers, an important etiologic role is played by environmental and biological factors. The factors involved are diet, low physical activity, obesity, and other related diseases such as ulcerative colitis. Many studies show that environmental factors, especially diet, have an essential etiologic role in the etiology of colorectal cancer. ${ }^{6}$

\section{ETIOLOGY CANCER}

Etiology in cancer studies the relationship of risk factors in a certain period of exposure to the process of carcinogenesis itself. Exposure to certain risk factors is one mechanism of carcinogenesis. The risk factors can be endogenous factors and exogenous factors that have a direct or indirect effect on the tumor process. Exogenous factors are factors that predominantly come from exposure to the external environment (smoking, alcohol consumption, ionizing radiation, UV radiation, exposure to carcinogens, drugs, pathogens, and toxins), where each factor will act individually or together in the process. carcinogenesis.?

One of the risk factors that cannot be avoided either directly or indirectly contribute to the process of colorectal cancer, namely diet. Nutrition is a necessity for the survival of each individual, so it is necessary to pay attention to what food is consumed and what substance content can be given. In addition to nutrition, the caloric value in food also plays a special role in providing a feeling of fullness. It is important to regulate the composition of food and the proper ratio of vitamins, minerals, fats, carbohydrates, and proteins. Another important thing to note is the presence of additives and emulsifiers added to food, especially factory production. ${ }^{8}$ The mechanism of colorectal cancer is associated with poor long-term exposure to ingested food and exposure to carcinogenic substances. At present, attention has been paid to quality of life which considers lifestyle as a determinant of organ function and general health conditions of individuals. ${ }^{9}$

\section{THE ROLE OF APOPTOSIS IN COLON CANCER}

Colorectal cancer is a developmental result of the pathological transformation of normal colonic epithelium into adenomatous polyps and then develops into invasive cancer. The development process of colorectal cancer takes a long time to years or decades which can be accompanied by genetic changes. The process of colorectal cancer carcinogenesis is influenced by the presence of a number of mutated genes. Mutations in tumor suppressor genes and proto-oncogenes can enhance cell proliferative processes and contribute to the development of invasive cancer. The body already has a physiological process that plays an 
important role in restoring normal tissue and embryonic development with programmed cell death, namely apoptosis. Apoptosis has a major function in balancing cell proliferation and eradicating excess cells without causing an inflammatory reaction or potential harm to the host. Three morphological stages have been identified in cells undergoing apoptosis. In the early stages, the cell will experience size shrinkage followed by chromatin condensation and organelle aggregation. Membrane blebbing, the formation of vesicles from the plasma membrane containing various cellular components are characteristic of the second stage. The final stage is characterized by degeneration of nuclear material and cellular structures within apoptotic bodies. Apoptosis is very different from necrosis, where the process of necrosis results in the release of cellular content and the induction of inflammation. ${ }^{10}$

There are several genes that regulate the process of apoptosis such as Bcl-2, p53 and cmyc. The p53 gene located on the short arm of chromosome 17 has an important role in regulating the cell cycle. The expression of $\mathrm{p} 53$ protein will stop the G1 stage in the cell cycle and give the cell time to repair the DNA damage that occurs. The p53 gene in $75 \%$ of colorectal cancers has a gene deletion. An experimental study with non-Bcl-2 mice showed an increase in intestinal cell loss accompanied by exfoliation as well as a significant decrease in mitotic progenitor cells. These results show the functional role that $\mathrm{Bcl}-2$ has in regulating cell turnover. ${ }^{11}$

\section{DIET}

There are several low dietary factors involved in colorectal carcinogenesis, namely consumption of high calories, high fat, low calcium, and vitamins. Various mechanisms have also been carried out related to the effect of food components on the carcinogenesis process. The mechanisms involved are the destruction of the colonic mucosa due to bile acids, DNA damage due to lipid peroxidation, changes in the metabolism of colonic bacteria, and the insufficient protective role of antioxidants. ${ }^{12}$ Several studies have shown the incidence of colorectal cancer with the consumption of a high-fat diet such as red meat and vegetable fats. ${ }^{13,14}$
Consumption of high-fiber foods can reduce the risk of colorectal cancer. This is hypothesized through the consumption pattern of Africans with a high-fiber diet to have a low death rate from colorectal cancer. $^{15}$

\section{DIETARY COMPONENTS ASSOCIATED WITH CRC RISK}

\section{Fat}

Traditionally, the basic human diet is eating foods from plant sources that incidentally have low fat content. This is in stark contrast to the current situation, where dietary trends have evolved with a significant increase in consumption of saturated fats and animal fats. ${ }^{16}$ Longterm exposure to saturated fat and animal fats significantly increases the risk of cardiovascular disease, diabetes, and cancer (breast, prostate, and colorectal). ${ }^{17}$ Follow-up research with randomized control trials found that a very low-fat vegan diet can reduce the risk of chronic diseases such as cancer, so it can be hypothesized that a low-fat diet can reduce the risk of colorectal cancer. ${ }^{18}$

\section{Red Meat}

Recent research reports that daily consumption of 50 grams of meat increases the risk of developing colorectal cancer by $20 \% .{ }^{19}$ Another study reported that the association between the incidence of colorectal cancer and consumption of red meat varied between individuals. ${ }^{20}$ This can be related to the carcinogenic aspect obtained from the processing. Research evidence shows that consumption of 70 grams of cooked red meat increases the risk of colorectal cancer by $29 \%$ compared to rare or moderately cooked red meat. ${ }^{21}$ The genetic direction that varies between individuals affects the sensitivity to carcinogenic exposure from cooked meat. this tendency increases the development of colorectal cancer compared to individuals without the gene. ${ }^{22}$ The evidence for an association between red meat and an increased risk of colorectal cancer is not yet fully conclusive, but several studies have shown a significant association.

\section{Processed meat}

There is ample evidence to support the hypothesis of an association between processed meat consumption and an increased risk of colorectal cancer. Studies show consumption of 25 grams of processed meat per day increases the risk of colorectal cancer by $49 \%{ }^{23,24}$ The content of nitrous oxide as a preservative in processed meat has been closely associated with the incidence of colorectal cancer, so it can be assumed that processed meat is more potent in increasing the risk of colorectal cancer than red meat. ${ }^{25}$

\section{Refined carbohydrates}

Studies report that increased consumption of refined carbohydrates is associated with a significantly increased risk of chronic diseases such as diabetes, cardiovascular disease, cancer, especially colorectal cancer. ${ }^{26}$ The content of vitamins, minerals, and dietary fiber in refined carbohydrates is greatly reduced as a result of the processing. The low dietary fiber content of refined carbohydrates makes them very easy to break down, leading to a rapid increase in blood glucose levels. The rapid increase in blood glucose levels will cause the release of insulin also takes place quickly. High insulin requirements will trigger the production of the hormone insulin growth factor-1 (IGF-1). The IGF1 hormone will increase cell proliferation which in turn is able to encourage the growth of cancer cells, especially in colorectal cancer. ${ }^{27}$ The increasing consumption of refined carbohydrates such as white bread, white rice, and white pasta, can trigger the loss of protection from raw carbohydrates against chronic diseases such as colorectal cancer. ${ }^{15}$

\section{PROTECTIVE DIETARY COMPONENTS AND CRC RISK}

\section{Dietary fibers}

Sources of dietary fiber can be obtained from fruits, vegetables, whole grains, nuts, and tubers. There are two types of dietary fiber, namely soluble fiber and insoluble fiber. Insoluble fiber is important in preventing and treating constipation which can be obtained from whole grains and legumes. Soluble fiber plays a role in lowering blood cholesterol and stabilizing blood glucose which is obtained from fruits and vegetables. In addition, dietary fiber has an essential role in the colon, where dietary fiber can increase the mass 
of feces, increase the content of bacteria in the stool, increase the water content of the stool, increase the frequency of defecation, reduce intracolonal pressure, and reduce the transit time of feces in the colon. ${ }^{28}$ Burkitt in 1971, found a relationship between high dietary fiber consumption and a low incidence of colorectal cancer. In addition, a low incidence of colorectal cancer is found in the African region. This is related to a pattern of consumption of a diet high in raw carbohydrates or dietary fiber. ${ }^{29}$ The study found that doubling the dietary fiber intake of a population with a low average intake of fiber could reduce the risk of colorectal cancer by $40 \%$, thus supporting that dietary fiber intake is inversely related to incidence of colorectal cancer. $^{30}$

\section{Wholegrain/ Cereals}

Fiber-rich food sources can be obtained from whole grains. Dietary fiber in grains will undergo a fermentation process in the colon by microflora, where the fiber will turn into short chain fatty acids and gas. The presence of short chain fatty acid production is associated with a reduced risk of colorectal cancer. ${ }^{31}$ The hypothesis of dietary fiber consumption and a reduced risk of colorectal cancer has been supported by a number of studies. Whole grain intake was found to have an inverse relationship with a reduced risk of colorectal cancer. ${ }^{30}$ Furthermore, a review of 58 epidemiological studies reported that cereals provide a protective effect against colorectal cancer. ${ }^{32}$

\section{Fruit, vegetables and legumes}

Studies have shown that regular consumption of fruits and vegetables is associated with a reduced incidence of chronic diseases, including cancer. ${ }^{33,34}$ An 18-year cohort study reported that consumption of four or more servings of legumes per week had a lower incidence of colorectal adenoma than consumption of one or less servings per week. ${ }^{35}$ These results still need attention, especially the average intake of participants is 16.7 grams / day and is below the recommended average intake of 3040 grams / day. In addition, there is a possibility of dishonesty by respondents in providing information on changes in diet in the last 8 years, so that the results of the questionnaire do not accurately reflect fiber intake. ${ }^{36} \mathrm{~A}$ systematic review of five randomized controlled trials showed no evidence of dietary fiber reducing the incidence of colorectal cancer over a 2 to 4 year period. ${ }^{37}$

\section{Folate and carotenoids}

Various nutrients contained in vegetables such as folate and carotenoids are associated with a reduced risk of colorectal cancer. ${ }^{38}$ Sources of folate from food can be obtained from green leafy vegetables. Studies report that long-term consumption of folate in the form of folic acid (10-15 years) can significantly reduce the risk of colorectal cancer. ${ }^{39}$

\section{Lycopene}

Studies show that consumption of tomatoes has a protective effect against colorectal cancer. Lycopene is a powerful carotenoid antioxidant found in tomatoes. Lycopene has been linked to a reduced risk of cancer including colorectal cancer. Lycopene will have a high bioavailability when heated, so the cooking process increases lycopene levels. ${ }^{40}$ Lycopene has been studied to reduce the possibility of cancer cells developing in the colon and play a role in the process of apoptosis. ${ }^{41}$ Unfortunately, recent studies have shown that lycopene has only a small impact in reducing the risk of colorectal cancer. The study only lasted for 2 weeks so there is a possibility of bias towards the results of the study. ${ }^{42}$

\section{Body fatness}

There is a significant relationship between obesity and lack of exercise with the risk of colorectal cancer, ${ }^{43}$ so it is necessary to promote health to always do exercise regularly as a prevention of the risk of colorectal cancer. ${ }^{44,45}$

\section{CONCLUSION}

The majority of colorectal cancer is thought to be due to dietary factors, so diet and lifestyle are key points of intervention in primary prevention. Consumption of high-energy diets, consumption of red or processed meats, high glycemic index diets (carbohydrates, snacks, and fast food) have been associated with an increased risk of colorectal cancer. In contrast, consumption of dietary fiber, whole grains, fruit, vegetables, nuts, lycopene, as well as folate and carotenoids can even reduce the occurrence of colorectal cancer.

\section{DISCLOSURE}

\section{Author Contribution}

All authors have contributed equally in preparing this review article.

\section{Conflict of Interest}

All authors declared no conflict of interest regarding the topic and publishing this article.

\section{Funding}

None.

\section{Ethical Consideration}

Ethical consideration was not appropriate for this review.

\section{REFERENCES}

1. Weitz J, Koch M, Debus J, Höhler T, Galle PR, Büchler MW. Colorectal cancer. Lancet. 2005;365(9454):153-65. Available from: http:// dx.doi.org/10.1016/s0140-6736(05)17706-x

2. Center MM, Jemal A, Ward E. International Trends in Colorectal Cancer Incidence Rates. Cancer Epidemiol Biomarkers Prev. 2009;18(6):1688-94. Available from: http:// dx.doi.org/10.1158/1055-9965.epi-09-0090

3. Shike M. Diet and lifestyle in the prevention of colorectal cancer: an overview. Am J Med. 1999;106(1):11-5. Available from: http://dx.doi. org/10.1016/s0002-9343(98)00340-4

4. Kasdagly M, Radhakrishnan S, Reddivari L, Veeramachaneni DNR, Vanamala J. Colon carcinogenesis: Influence of Western dietinduced obesity and targeting stem cells using dietary bioactive compounds. Nutrition. 2014;30(11-12):1242-56. Available from: http://dx.doi.org/10.1016/j.nut.2014.02.016

5. Popkin BM, Adair LS, Ng SW. Global nutrition transition and the pandemic of obesity in developing countries. Nutr Rev. 2012;70(1):321. Available from: https://pubmed.ncbi.nlm. nih.gov/22221213

6. Muir CS, Parkin DM. The world cancer burden: prevent or perish. $\mathrm{Br}$ Med J (Clin Res Ed). 1985;290(6461):5-6. Available from: https:// pubmed.ncbi.nlm.nih.gov/3917333

7. Sanz-Barbero B, Prieto-Flores ME, OteroGarcía L, Abt-Sacks A, Bernal M, Cambas N. Percepción de los factores de riesgo de cáncer por la población española. Gac Sanit. 2014;28(2):137-45. Available from: http:// dx.doi.org/10.1016/j.gaceta.2013.10.008

8. Jurisic V, Stojacic-Djenic S, Colovic N, Konjevic $\mathrm{G}$. The role of cytokine in regulation of the natural killer cell activity. Srp Arh Celok Lek. 2008;136(7-8):423-9. Available from: http:// dx.doi.org/10.2298/sarh0808423j 
9. Takagi Y, Sakai N, Yoshitomi H, Furukawa K, Takayashiki T, Kuboki S, et al. High expression of Krüppel-like factor 5 is associated with poor prognosis in patients with colorectal cancer. Cancer Sci. 2020/05/05. 2020;111(6):2078-92. Available from: https://pubmed.ncbi.nlm.nih. gov/32279400

10. Pritchard DM, Watson AJM. Apoptosis and gastrointestinal pharmacology. Pharmacol Ther. 1996;72(2):149-69. Available from: http:// dx.doi.org/10.1016/s0163-7258(96)00102-7

11. Kamada S, Shimono A, Shinto Y, Tsujimura T, Takahashi T, Noda T, et al. bcl-2 deficiency in mice leads to pleiotropic abnormalities: accelerated lymphoid cell death in thymus and spleen, polycystic kidney, hair hypopigmentation, and distorted small intestine. Cancer Res. 1995;55(2):354-9.

12. Shike M, Winawer SJ, Greenwald PH, Bloch A, Hill MJ, Swaroop S V. Primary prevention of colorectal cancer. The WHO Collaborating Centre for the Prevention of Colorectal Cancer. Bull World Health Organ. 1990;68(3):377-85.

13. Willett WC, Stampfer MJ, Colditz GA, Rosner BA, Speizer FE. Relation of Meat, Fat, and Fiber Intake to the Risk of Colon Cancer in a Prospective Study among Women. N Engl J Med. 1990;323(24):1664-72. Available from: http:// dx.doi.org/10.1056/nejm199012133232404

14. Enig MG, Munn RJ, Keeney M. Dietary fat and cancer trends--a critique. Fed Proc. 1978;37(9):2215-20.

15. Burkitt DP. Epidemiology of cancer of the colon and rectum. Cancer. 1971;28(1):3-13. Available from: http://dx.doi.org/10.1002/10970142 ( 197107 ) 28:1\%3 C 3 : : a id cncr2820280104\%3E3.0.co

16. Campos FG, Logullo Waitzberg AG, Kiss DR, Waitzberg DL, Habr-Gama A, Gama-Rodrigues J. Diet and colorectal cancer: current evidence for etiology and prevention. Nutr Hosp. 2005;20(1):18-25.

17. Eyre H, Kahn R, Robertson RM. Preventing Cancer, Cardiovascular Disease, and Diabetes: A common agenda for the American Cancer Society, the American Diabetes Association, and the American Heart Association. Diabetes Care. 2004;27(7):1812-24. Available from: http://dx.doi.org/10.2337/diacare.27.7.1812

18. Dewell A, Weidner G, Sumner MD, Chi CS, Ornish D. A Very-Low-Fat Vegan Diet Increases Intake of Protective Dietary Factors and Decreases Intake of Pathogenic Dietary Factors. J Am Diet Assoc. 2008;108(2):347-56. Available from: http://dx.doi.org/10.1016/j. jada.2007.10.044

19. Wiseman M. The second world cancer research fund/American institute for cancer research expert report. Food, nutrition, physical activity, and the prevention of cancer: a global perspective: Nutrition Society and BAPEN Medical Symposium on 'nutrition support in canc. Proc Nutr Soc. 2008;67(3):253-6.

20. Norat T, Lukanova A, Ferrari P, Riboli E. Meat consumption and colorectal cancer risk: Doseresponse meta-analysis of epidemiological studies. Int $J$ Cancer. 2002;98(2):241-56. Available from: http://dx.doi.org/10.1002/ ijc.10126
21. Sinha R, Chow WH, Kulldorff M, Denobile J, Butler J, Garcia-Closas M, et al. Well-done, grilled red meat increases the risk of colorectal adenomas. Cancer Res. 1999;59(17):4320-4.

22. Lilla C, Risch A, Verla-Tebit E, Hoffmeister $\mathrm{M}$, Brenner $\mathrm{H}$, Chang-Claude J. SULT1A1 genotype and susceptibility to colorectal cancer. Int J Cancer. 2006;120(1):201-6. Available from: http://dx.doi.org/10.1002/ijc.22156

23. Sandhu MS, White IR, McPherson K. Systematic review of the prospective cohort studies on meat consumption and colorectal cancer risk: a meta-analytical approach. Cancer Epidemiol biomarkers Prev a Publ Am Assoc Cancer Res cosponsored by Am Soc Prev Oncol. 2001;10(5):439-46.

24. Norat T, Bingham S, Ferrari P, Slimani N, Jenab M, Mazuir M, et al. Meat, fish, and colorectal cancer risk: the European Prospective Investigation into cancer and nutrition. J Natl Cancer Inst. 2005;97(12):906-16.

25. Franceschi S, Russo A, Vecchia C la. Carbohydrates, fat and cancer of the breast and colon-rectum. J Epidemiol Biostat (United Kingdom). 1998;

26. Jenkins DJA, Kendall CWC, Marchie A, Augustin LSA. Too much sugar, too much carbohydrate, or just too much? Am J Clin Nutr. 2004;79(5):711-2. Available from: http://dx.doi. org/10.1093/ajen/79.5.711

27. Barker HM, Lees R. Nutrition and dietetics for health care. Churchill Livingstone Inc.,; 1996.

28. Cotugna N. Dietary factors and cancer risk. Semin Oncol Nurs. 2000;16(2):99-105. Available from: http://dx.doi.org/10.1053/on.2000.5737

29. Boyle P, Langman JS. ABC of colorectal cancer: Epidemiology. BMJ. 2000;321(7264):805-8. Available from: https://pubmed.ncbi.nlm.nih. gov/11009523

30. Bingham SA, Day NE, Luben R, Ferrari P, Slimani N, Norat T, et al. Dietary fibre in food and protection against colorectal cancer in the European Prospective Investigation into Cancer and Nutrition (EPIC): an observational study. Lancet. 2003;361(9368):1496-501. Available from: $\quad$ http://dx.doi.org/10.1016/s01406736(03)13174-1

31. Hill MJ. Cereals, cereal fibre and colorectal cancer risk. Eur J Cancer Prev. 1998;7(2):S510. Available from: http://dx.doi. org/10.1097/00008469-199805000-00002

32. Fuchs CS, Giovannucci EL, Colditz GA, Hunter DJ, Stampfer MJ, Rosner B, et al. Dietary Fiber and the Risk of Colorectal Cancer and Adenoma in Women. N Engl J Med. 1999;340(3):169-76. Available from: http://dx.doi.org/10.1056/ nejm199901213400301

33. Michels KB, Giovannucci E, Chan AT, Singhania R, Fuchs CS, Willett WC. Fruit and Vegetable Consumption and Colorectal Adenomas in the Nurses' Health Study. Cancer Res. 2006;66(7):3942-53. Available from: http:// dx.doi.org/10.1158/0008-5472.can-05-3637

34. Swari RP, Sueta MAD, Adnyana MS. Hubungan asupan serat dengan angka kejadian kanker kolorektal di RSUP Sanglah Denpasar tahun 2016 - 2017. Intisari Sains Medis. 2019;10(2). Available from: http://dx.doi.org/10.15562/ism. v10i2.262
35. Lawlor DA, Ness AR. Commentary: The rough world of nutritional epidemiology: Does dietary fibre prevent large bowel cancer? Int $J$ Epidemiol. 2003;32(2):239-43. Available from: http://dx.doi.org/10.1093/ije/dyg060

36. Terry P, Giovannucci E, Michels KB, Bergkvist L, Hansen H, Holmberg L, et al. Fruit, Vegetables, Dietary Fiber, and Risk of Colorectal Cancer. JNCI J Natl Cancer Inst. 2001;93(7):525-33. Available from: http://dx.doi.org/10.1093/ jnci/93.7.525

37. Meier R, Gassull MA. Consensus recommendations on the effects and benefits of fibre in clinical practice. Clin Nutr Suppl. 2004;1(2):73-80. Available from: http://dx.doi. org/10.1016/j.clnu.2004.09.011

38. Cummings JH, Bingham SA. Diet and the prevention of cancer. $B M J$. 1998;317(7173):1636-40. Available from: https://pubmed.ncbi.nlm.nih.gov/9848907

39. Perera CO, Yen GM. Functional Properties of Carotenoids in Human Health. Int J Food Prop. 2007;10(2):201-30. Available from: http:// dx.doi.org/10.1080/10942910601045271

40. Walfisch S, Walfisch Y, Kirilov E, Linde N, Mnitentag H, Agbaria R, et al. Tomato lycopene extract supplementation decreases insulin-like growth factor-I levels in colon cancer patients. Eur J Cancer Prev. 2007;16(4):298-303. Available from: http://dx.doi.org/10.1097/01. cej.0000236251.09232.7b

41. Palozza P, Serini S, Boninsegna A, Bellovino D, Lucarini M, Monastra G, et al. The growthinhibitory effects of tomatoes digested in vitro in colon adenocarcinoma cells occur through down regulation of cyclin D1, Bcl-2 and Bcl-xL. Br J Nutr. 2007;98(04). Available from: http:// dx.doi.org/10.1017/s0007114507746883

42. Schnäbele K, Briviba K, Bub A, Roser S, PoolZobel BL, Rechkemmer G. Effects of carrot and tomato juice consumption on faecal markers relevant to colon carcinogenesis in humans. $\mathrm{Br} \mathrm{J}$ Nutr. 2008;99(3):606-13. Available from: http:// dx.doi.org/10.1017/s0007114507819143

43. Trisuladara AASM, Sueta MAD, Adnyana MS. Hubungan antara obesitas dan insiden kanker kolorektal di RSUP Sanglah tahun 2016-2017. Intisari Sains Medis. 2019;10(2). Available from: http://dx.doi.org/10.15562/ism.v10i2.278

44. White V, Miller R. Colorectal cancer: prevention and early diagnosis. Medicine (Baltimore). 2007;35(6):297-301. Available from: http:// dx.doi.org/10.1016/j.mpmed.2007.03.001

45. Chan AT, Giovannucci EL, Meyerhardt JA, Schernhammer ES, Curhan GC, Fuchs CS. Long-term use of aspirin and nonsteroidal anti-inflammatory drugs and risk of colorectal cancer. JAMA. 2005;294(8):914-23. Available from: https://pubmed.ncbi.nlm.nih. gov/16118381

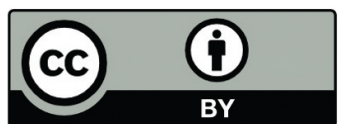

This work is licensed under a Creative Commons Attribution 